\title{
BACE1 Knock-Outs Display Deficits in Activity-Dependent Potentiation of Synaptic Transmission at Mossy Fiber to CA3 Synapses in the Hippocampus
}

\author{
Hui Wang, ${ }^{1,2}$ Lihua Song, ${ }^{1}$ Fiona Laird, ${ }^{3,4}$ Philip C. Wong, ${ }^{3,4}$ and Hey-Kyoung Lee ${ }^{1,2}$ \\ ${ }^{1}$ Department of Biology, College of Chemical and Life Sciences, and ${ }^{2}$ Neuroscience and Cognitive Science Program, University of Maryland, College Park, \\ Maryland 20742, and Departments of ${ }^{3}$ Pathology and ${ }^{4}$ Neuroscience, Johns Hopkins University School of Medicine, Baltimore, Maryland 21205
}

\begin{abstract}
$\beta$-Amyloid precursor protein cleavage enzyme 1 (BACE1) has been identified as a major neuronal $\beta$-secretase critical for the formation of $\beta$-amyloid $(\mathrm{A} \beta)$ peptide, which is thought responsible for the pathology of Alzheimer's disease (AD). Therefore, BACE1 is one of the key therapeutic targets that can prevent the progression of AD. Previous studies showed that knocking out the BACE1 gene prevents $\mathrm{A} \beta$ formation, but results in behavioral deficits and specific synaptic dysfunctions at Schaffer collateral to CA1 synapses. However, BACE1 protein is most highly expressed at the mossy fiber projections in CA3. Here, we report that BACE1 knock-out mice display reduced presynaptic function, as measured by an increase in paired-pulse facilitation ratio. More dramatically, mossy fiber long-term potentiation (LTP), which is normally expressed via an increase in presynaptic release, was eliminated in the knock-outs. Although long-term depression was slightly larger in the BACE1 knock-outs, it could not be reversed. The specific deficit in mossy fiber LTP was upstream of cAMP signaling and could be "rescued" by transiently elevating extracellular $\mathrm{Ca}^{2+}$ concentration. These results suggest that BACE1 may play a critical role in regulating presynaptic function, especially activity-dependent strengthening of presynaptic release, at mossy fiber synapses.
\end{abstract}

Key words: long-term potentiation; long-term depression; presynaptic; paired-pulse facilitation; beta-secretase; Alzheimer's disease

\section{Introduction}

Alzheimer's disease $(\mathrm{AD})$ is the most prevalent form of senile dementia. Current treatment of $\mathrm{AD}$ remains limited, and there is no effective disease-modifying treatment as of yet (Citron, $2004 \mathrm{~b}$ ). It is widely believed that AD is initiated as a synaptic dysfunction which correlates with the loss of memory function in the early stages of the disease (Selkoe, 2002). A current hypothesis states that overproduction of $\beta$-amyloid $(\mathrm{A} \beta)$ peptide initiates the pathogenesis of AD (Hardy and Selkoe, 2002; Citron, 2004b; Walsh and Selkoe, 2007). A $\beta$ is produced by the sequential cleavage of amyloid precursor proteins (APPs) by $\beta$ - and $\gamma$-secretases which are one of the major disease-modifying targets to treat AD (Citron, 2004b). However, it became apparent that $\gamma$-secretase processes other critical substrates essential for normal cell development and function, such as Notch (Sisodia and St GeorgeHyslop, 2002; Selkoe and Kopan, 2003). Therefore, inhibiting $\beta$-secretase is now receiving renewed attention (Vassar, 2002; Citron, 2004a,b). The amount and activity of $\beta$-secretase is elevated in sporadic AD brains (Yang et al., 2003; Li et al., 2004; Zhao et al., 2007), further suggesting that effective methods to reduce its activity may be beneficial to a large population of $\mathrm{AD}$ patients.

Received May 30, 2008; revised July 11, 2008; accepted July 19, 2008.

This work was supported by National Institutes of Health Grant P01-NS047308.

Correspondence should be addressed to Hey-Kyoung Lee, Department of Biology, University of Maryland, 1210

Biology-Psychology Building, College Park, MD 20742. E-mail: hlee21@umd.edu.

DOI:10.1523/JNEUROSCI.2440-08.2008

Copyright $\odot 2008$ Society for Neuroscience $\quad$ 0270-6474/08/288677-05\$15.00/0
A transmembrane aspartic protease, $\beta$-site APP cleavage enzyme 1 (BACE1), was identified as the major neuronal $\beta$-secretase (Hussain et al., 1999; Sinha et al., 1999; Vassar et al., 1999; Yan et al., 1999). BACE1 knock-out (KO) mice were generated to determine the functional consequences of chronically inhibiting the activity of $\beta$-secretase. Initial characterization of the BACE1 knock-outs suggested that there are no gross anatomical or functional abnormalities (Luo et al., 2001, 2003). Moreover, knocking out BACE1 in APP transgenic lines, which normally develop $\mathrm{A} \beta$ plaques and behavioral deficits, essentially alleviated the AD symptoms (Luo et al., 2003; Ohno et al., 2004; Laird et al., 2005). However, recent studies, including our own, showed that BACE1 knock-outs display specific dysfunctions in synaptic transmission and plasticity (Ohno et al., 2004; Laird et al., 2005), as well as behavioral deficits (Harrison et al., 2003; Laird et al., 2005; Savonenko et al., 2008). Although all of the studies characterizing synaptic function of BACE1 knock-outs thus far have been performed in the CA1 region of the hippocampus (Ohno et al., 2004; Laird et al., 2005; Ma et al., 2007), the expression of BACE1 is most prominent in the mossy fiber terminals that synapse onto CA3 pyramidal neurons (Laird et al., 2005; Zhao et al., 2007). Therefore, we examined synaptic function and plasticity of the BACE1 knock-outs at the mossy fiber synapses.

\section{Materials and Methods}

Animals. All mice used (BACE1 $+/+$ and $-/-$ ) were derived from heterozygous breeders (+/-) as described previously (Laird et al., 2005). The Institutional Animal Care and Use Committees of both University of 
Maryland, College Park and Johns Hopkins University approved all procedures involving animals.

Electrophysiological recordings. Hippocampal slices (400 $\mu \mathrm{m}$ thick) were prepared from adult (3-6 months old) male BACE1 knock-out and wild-type (WT) mice as described previously (Laird et al., 2005). Briefly, hippocampi were sliced in ice-cold dissection buffer (in mм: 212.7 sucrose, $2.6 \mathrm{KCl}, 1.23 \mathrm{NaH}_{2} \mathrm{PO}_{4}, 26 \mathrm{NaHCO}_{3}, 10$ dextrose, $\mathrm{MgCl}_{2}$, and 1 $\mathrm{CaCl}_{2}$, saturated with $5 \% \mathrm{CO}_{2}$ and $\left.95 \% \mathrm{O}_{2}\right)$. Recordings were done in a submersion-type recording chamber perfused with artificial CSF (ACSF) (in mm: $124 \mathrm{NaCl}, 5 \mathrm{KCl}, 1.25 \mathrm{NaH}_{2} \mathrm{PO}_{4}, 26 \mathrm{NaHCO}_{3}, 10$ dextrose, 1.5 $\mathrm{MgCl}_{2}$, and $2.5 \mathrm{CaCl}_{2}$, saturated with $5 \% \mathrm{CO}_{2}$ and $95 \% \mathrm{O}_{2}, 29.5-30.5^{\circ} \mathrm{C}$, $2 \mathrm{ml} / \mathrm{min}$ ). Synaptic responses were evoked through bipolar stimulating electrodes (double-barreled borosilicate glass capillaries; Sutter Instrument), placed in the dentate granule cell layer to activate the mossy fibers with pulse durations of $0.2 \mathrm{~ms}$ (baseline stimulation, $0.067 \mathrm{~Hz}$ ), and recorded extracellularly in the stratum lucidum of CA3. Both the stimulating and recording electrodes were filled with ACSF. To induce longterm potentiation (LTP), three trains of $100 \mathrm{~Hz}(1 \mathrm{~s})$ stimuli were given at $20 \mathrm{~s}$ intervals. Long-term depression (LTD) was induced by a pairedpulse $1 \mathrm{~Hz}$ protocol [interstimulus interval (ISI), $50 \mathrm{~ms} ; 15 \mathrm{~min}$ ]. For measurement of paired-pulse facilitation (PPF), ISIs of 25, 50, 100, 200, 400,1000 , and $2000 \mathrm{~ms}$ were used. In some experiments, extracellular $\mathrm{Ca}^{2+}$ concentration was increased to $5.0 \mathrm{~mm}$ for $10 \mathrm{~min}$ before delivering high-frequency stimulation (HFS) (Castillo et al., 2002). To activate cAMP production, $50 \mu \mathrm{M}$ forskolin (Sigma-Aldrich) was applied for 5 min. All experiments were done in the presence of $100 \mu \mathrm{M}$ DL-APV (DL2-amino-5-phosphonovaleric acid) (Sigma-Aldrich) to block NMDA receptors. At the end of each experiment, $1 \mu \mathrm{M}\left(2 S, 2^{\prime} R, 3^{\prime} R\right)-2-\left(2^{\prime}, 3^{\prime}-\right.$ dicarboxycyclopropyl)glycine (DCG-IV) (Tocris Bioscience) was added, and blockade $\geq 80 \%$ were taken to be mossy fiber inputs. Field potential (FP) slopes were measured, and data are expressed as mean $\pm \mathrm{SE}$ of mean.

\section{Results}

Reduction in presynaptic function at mossy fiber synapses in BACE1 knock-outs

We observed previously that mossy fiber terminals are enriched in BACE1 protein compared with other hippocampal subfields (Laird et al., 2005). Therefore, we hypothesized that BACE1 knock-outs may exhibit alterations in synaptic transmission and plasticity at this particular set of synapses. We first measured presynaptic function by comparing PPF ratio at various ISIs. We found a significant interaction between the genotype and ISIs (two-factor ANOVA, genotype $\times$ ISI: $F_{(6,203)}=2.586, p<0.02$ ), particularly BACE1 KOs, displayed larger PPF ratios at shorter ISIs (25 ms ISI: WT, $3.4 \pm 0.57 ; \mathrm{KO}, 6.1 \pm 0.79 ; 50$ ms ISI: WT, $3.6 \pm 0.65, n=14 ; \mathrm{KO}, 5.7 \pm 0.77, n=17$; Fisher's PLSD post hoc test, $p<0.002$ for 25 and $50 \mathrm{~ms}$ ISI between WT and KO) (Fig. $1 A)$. The increase in PPF ratio suggests a reduction in presynaptic release. Synaptic transmission at mossy fiber to CA3 synapses display sensitivity to group II metabotropic glutamate receptor (mGluR) agonists (Nicoll and Schmitz, 2005). Bath application of $1 \mu \mathrm{M}$ DCG-IV at the end of the recording produced a comparable reduction in basal synaptic transmission in both knockouts and wild types (WT, $12 \pm 4 \%$ of baseline at 20 min DCG-IV, $n=14 ; \mathrm{KO}, 11 \pm 2 \%, n=17)($ Fig. $1 B)$.

\section{Activity-dependent synaptic strengthening at mossy fiber synapses is abolished in BACE1 knock-outs}

Next, we examined whether knocking out BACE1 affects synaptic plasticity at the mossy fiber synapses. We first compared LTP induced by HFS $(3 \times 100 \mathrm{~Hz}, 1 \mathrm{~s})$. BACE1 knock-outs showed a larger initial potentiation, suggesting an enhanced facilitation during HFS; however, the responses relaxed back to baseline by $1 \mathrm{~h}$ (WT: $149 \pm 10 \%$ of baseline at $1 \mathrm{~h}$ after HFS, $n=13$ slices from 6 mice; KO: $96 \pm 7 \%, n=16$ slices from 7 mice; $t$ test, $p<$
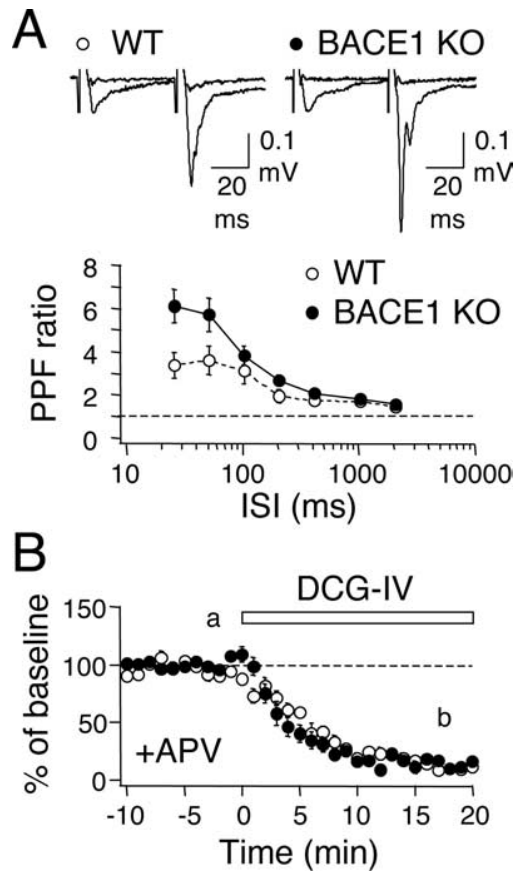

Figure 1. BACE1 knock-outs display a reduction in presynaptic function at the mossy fiber synapses. $\boldsymbol{A}$, Larger PPF ratio in BACE1 knock-outs. The difference between WT (white circles) and KOs (black circles) are significant at 25 and 50 ms ISIs. Top, Representative FP traces of paired-pulse stimulation at $50 \mathrm{~ms}$ ISI before and after DCG-IV application in wild type and knockout. The traces were taken from time points indicated ( $a$ and $b$ ) in the graph in $\boldsymbol{B}$. $\boldsymbol{B}$, Application of group II mGluR agonist (1 $\mu \mathrm{M} D C G-I V)$ reduces mossy fiber synaptic transmission in WT (white circles) and KOs (black circles).

0.01) (Fig. 2A). Consistent with a presynaptic locus of expression, LTP in wild types was accompanied by a decrease in PPF ratio measured at $50 \mathrm{~ms}$ ISI (baseline, $3.1 \pm 0.5 ; 1 \mathrm{~h}$ after HFS, $2.6 \pm 0.4 ; n=13$ slices from 6 mice; paired $t$ test, $p<0.03$ ), but knock-outs displayed a trend of a decrease in PPF ratio that returned to basal levels at $1 \mathrm{~h}$ (baseline, $5.9 \pm 1.0 ; 20 \mathrm{~min}$ after HFS, $3.6 \pm 0.5 ; 1 \mathrm{~h}$ after HFS, $6.1 \pm 1.2 ; n=16$ slices from 7 mice; ANOVA, $\left.F_{(2,45)}=2.018 ; p=0.1\right)$.

To test LTD, we used a paired-pulse $1 \mathrm{~Hz}$ protocol [PP-1 Hz (15 min) ], because a standard $1 \mathrm{~Hz}(15 \mathrm{~min})$ protocol (Kobayashi et al., 1996) failed to produce LTD in the wild types at the ages used for our study (data not shown). LTD induced by the PP-1 $\mathrm{Hz}$ was slightly, but significantly, larger in BACE1 knock-outs (WT: $75 \pm 4.3 \%$ of baseline at $1 \mathrm{~h}$ after onset of PP-1 Hz, $n=7$ slices from 5 mice; KO: $62 \pm 3.8 \%$ of baseline, $n=6$ slices from 4 mice; $t$ test, $p<0.04$ ) (Fig. $2 B$ ). This form of LTD did not significantly change PPF ratio either in wild types or knock-outs (WT: baseline, $3.8 \pm 1.0 ; 1 \mathrm{~h}$ after PP $1 \mathrm{~Hz}, 3.2 \pm 0.9, n=6$ slices from 4 mice; paired $t$ test, $p=0.16$; KO: baseline, $7.1 \pm 1.5 ; 1 \mathrm{~h}$ after PP $1 \mathrm{~Hz}, 5.5 \pm 1.1, n=6$ slices from 4 mice; paired $t$ test, $p=0.10$ ). Unlike in wild types, HFS failed to reverse LTD in the knock-outs (WT: $195 \pm 28.0 \%$ of renormalized baseline at $1 \mathrm{~h}$ after HFS, $n=$ 6 slices from 4 mice; KO: $100 \pm 5.4 \%, n=6$ slices from 4 mice; $t$ test, $p<0.02$ ) (Fig. $2 B$ ).

\section{Rescue of mossy fiber LTP in BACE1 knock-outs by} increasing extracellular $\mathrm{Ca}^{2+}$ concentration

Mossy fiber LTP is triggered by a rise in presynaptic $\mathrm{Ca}^{2+}$ (Castillo et al., 1994) and a further recruitment of cAMPdependent signaling mechanisms (Nicoll and Schmitz, 2005). Therefore, we investigated whether the lack of mossy fiber LTP in 

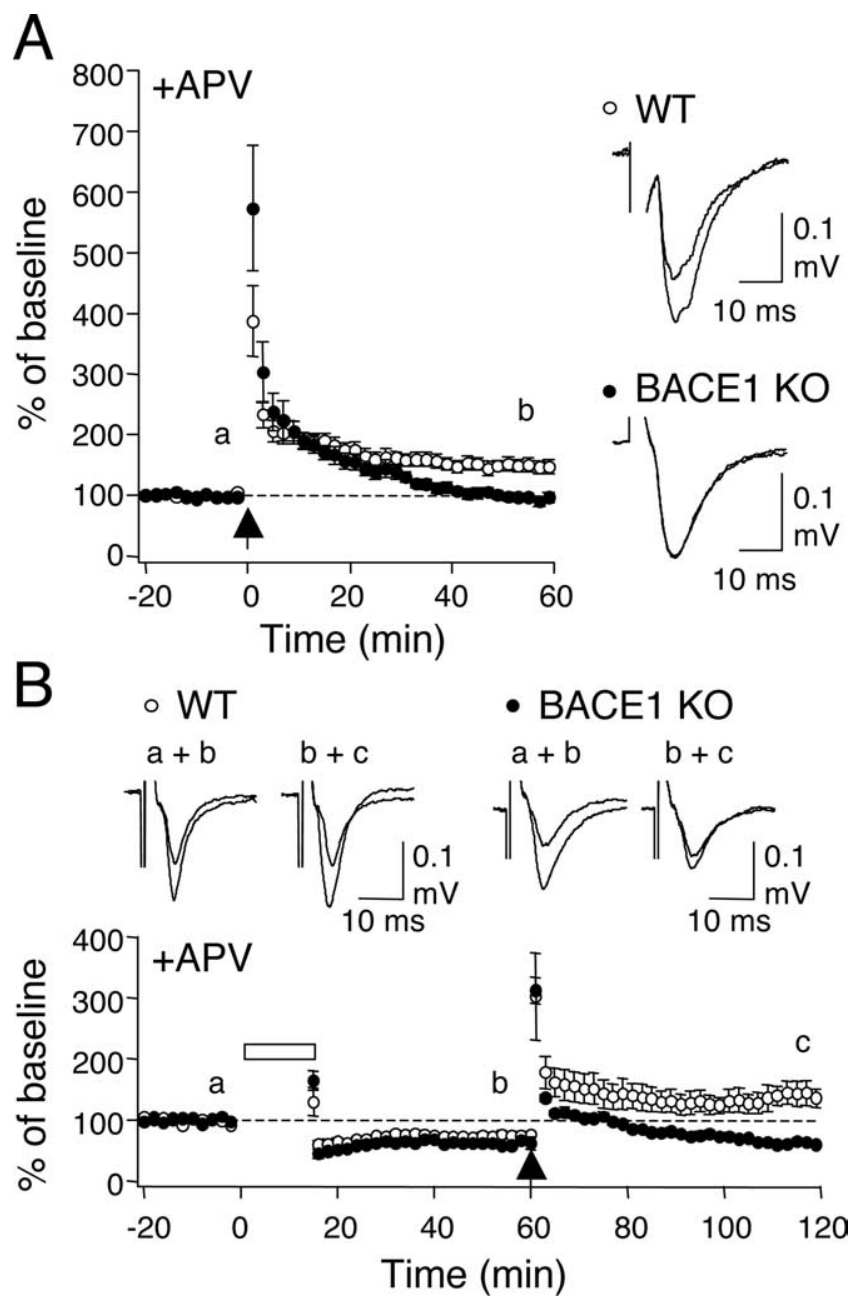

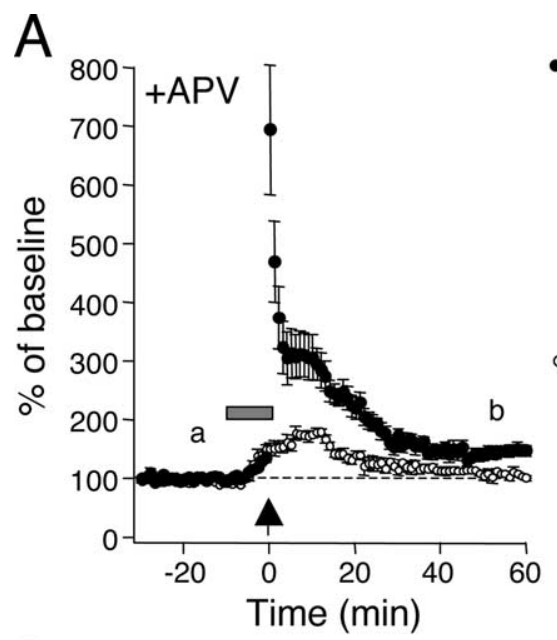

- BACE1 KO

(High $\left.\mathrm{Ca}^{2+}+\mathrm{HFS}\right)$

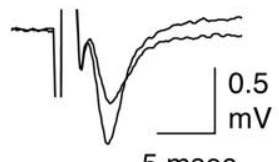

- BACE1 KO

(High $\mathrm{Ca}^{2+}$ alone)
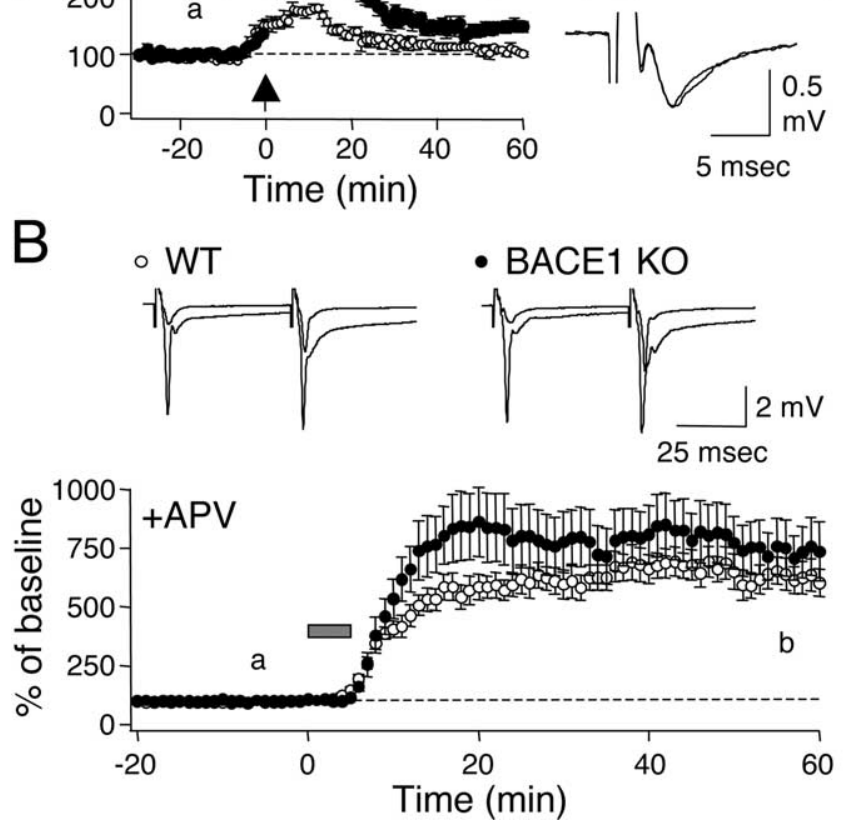

Figure 3. BACE1 knock-outs express mossy fiber LTP under high extracellular $\mathrm{Ca}^{2+}$ and produce normal forskolin-induced potentiation. $\boldsymbol{A}$, Transient elevation of external $\mathrm{Ca}^{2+}$ concentration ( $5 \mathrm{~mm} \mathrm{Ca}^{2+}, 10 \mathrm{~min}$; gray bar) rescued mossy fiber LTP in knock-outs (black circles). Increasing $\mathrm{Ca}^{2+}$ alone produced only a transient potentiation (open circles). The arrow depicts when HFS $(100 \mathrm{~Hz}, 1 s \times 3)$ was delivered. Right, Representative traces taken at times indicated (left graph, a and b). B, Transient application of forskolin ( $50 \mu \mathrm{m}, 5 \mathrm{~min}$; gray bar) potentiated mossy fiber synaptic transmission in wild types (open circles) and knock-outs (black circles) to the same magnitude. Top, Representative traces taken at times indicated (bottom panel, $a$ and b).

nitudes (WT: $622.5 \pm 57.8 \%$ of baseline at $1 \mathrm{~h}$ after forskolin, $n=$ 7 slices from 5 mice; KO: $741.8 \pm 110.1 \%, n=7$ slices from 4 mice; $t$ test, $p=0.36$ ) (Fig. $3 B$ ). This was accompanied by a significant decrease in PPF ratio in both genotypes (WT: baseline, $3.2 \pm 0.34 ; 1 \mathrm{~h}$ after forskolin, $1.5 \pm 0.15, n=7$ slices from 5 mice; paired $t$ test, $p<0.01$; KO: baseline, $4.9 \pm 0.63 ; 1 \mathrm{~h}$ after forskolin, $1.7 \pm 0.16, n=7$ slices from 4 mice; paired $t$ test, $p<0.01$ ), consistent with a presynaptic mechanism of potentiation. This demonstrates that the presynaptic deficits seen in BACE1 knockouts are upstream of cAMP signaling.

\section{Discussion}

We found that BACE1 knock-outs display severe deficits in presynaptic function at mossy fiber synapses in CA3: a reduction in presynaptic release and an absence of mossy fiber LTP. In addition, BACE1 knock-outs exhibited a slightly larger LTD which could not be reversed. These results suggest that BACE1 function is critical for normal synaptic transmission and plasticity, especially activity-dependent potentiation, at these synapses. We further found that the specific deficit in mossy fiber LTP in BACE1 knock-outs can be rescued by increasing extracellular $\mathrm{Ca}^{2+}$ con- 
centration. Because a direct activation of cAMP production was not impaired in the BACE1 knock-outs, our data suggest that the presynaptic dysfunction is likely at the level of presynaptic $\mathrm{Ca}^{2+}$ regulation.

Previous studies suggest that BACE1 is highly localized to presynaptic terminals, especially at the mossy fiber boutons in the CA3 (Laird et al., 2005; Zhao et al., 2007). This localization is consistent with our observation of a deficit in presynaptic function and plasticity at this synapse. Together with our previous results from the CA1 also showing an increase in PPF ratio (Laird et al., 2005), these results indicate that BACE1 may play a general role in regulating presynaptic function under physiological conditions. However, whether presynaptic deficits in BACE1 knockouts are directly attributable to lacking APP processing is unclear. Previous studies suggest that generation of excess $A \beta$ depresses excitatory synaptic transmission, mainly by postsynaptic removal of AMPA receptors and loss of synapses (Hsieh et al., 2006; Priller et al., 2006; Ting et al., 2007). These results would predict that lacking $\mathrm{A} \beta$ production, as in BACE1 knock-outs, would cause a postsynaptic increase in AMPA receptor function, not a decrease in presynaptic function as observed in our studies. However, we cannot rule out the possibility of gain-of-function in the $\mathrm{A} \beta$ overexpression studies.

Another possibility is that the presynaptic effects of BACE1 knock-out may be from abnormal processing of substrates other than APP. It is now known that BACE1 can also cleave APP-like proteins (Li and Südhof, 2004), $\beta$ subunits of voltage-gated $\mathrm{Na}^{+}$ channel (Wong et al., 2005; Kim et al., 2007), and neuregulin-1 (NRG1) (Hu et al., 2006; Willem et al., 2006). Regulation of the latter two substrates is particularly interesting. The $\beta 2$ subunit of $\mathrm{Na}^{+}$channel is critical for plasma membrane expression of functional $\mathrm{Na}^{+}$channels (Schmidt and Catterall, 1986), which are essential for action potential generation. However, overexpressing BACE1 actually decreases the density of functional $\mathrm{Na}^{+}$channels (Kim et al., 2007); hence, it cannot directly account for the observed reduction in presynaptic release in the BACE1 knock-outs. Potential regulation of NRG1 by BACE1 was discovered from observations that BACE1 knock-outs display a hypomyelination phenotype with a correlated accumulation of full-length NRG1 and a significant loss of NRG1 cleavage products (Hu et al., 2006; Willem et al., 2006). Recently, we demonstrated that the lack of NRG1 processing in BACE1 knock-outs reduces postsynaptic function of ErbB4, a receptor for NRG1 (Savonenko et al., 2008). NRG1/ErbB4 signaling has been suggested to regulate synaptic function and plasticity, mainly via regulation of postsynaptic glutamate receptors (Huang et al., 2000; Gu et al., 2005; Li et al., 2007). Nevertheless, abnormal processing of NRG1 may also affect presynaptic release by regulating the expression of nicotinic acetylcholine receptor (nAchR) subunit $\alpha 7$ (Liu et al., 2001), which allows $\mathrm{Ca}^{2+}$ influx (Séguéla et al., 1993). Indeed, presynaptic nAchRs can increase glutamate release (McGehee et al., 1995; Gray et al., 1996; Maggi et al., 2003), likely via the $\alpha 7$ containing nAchRs (Le Magueresse et al., 2006). These results suggest that lacking NRG1 cleavage, as in BACE1 knock-outs, would reduce presynaptic release. Whether this is the case for mossy fiber synapses is unclear (Vogt and Regehr, 2001).

Our results indicate that a complete inhibition of BACE1 activity is deleterious for neuronal function, especially at the mossy fiber synapses in CA3 compared with Schaffer collateral inputs in CA1. This suggests that mossy fiber dysfunction may have had a larger impact on the behavioral phenotypes seen in the BACE1 knock-outs (Harrison et al., 2003; Laird et al., 2005; Savonenko et al., 2008). We demonstrate that signaling downstream of presynaptic $\mathrm{Ca}^{2+}$ is intact in BACE1 knock-outs. Therefore, we were able to restore mossy fiber LTP in the BACE1 knock-outs by simply increasing extracellular $\mathrm{Ca}^{2+}$ concentration during LTP induction. This has significant clinical implications because it suggests that means to enhance presynaptic $\mathrm{Ca}^{2+}$ will circumvent synaptic deficits, and afterhaps alleviate the behavioral phenotypes, associated with inhibiting BACE1 activity.

\section{References}

Castillo PE, Weisskopf MG, Nicoll RA (1994) The role of Ca2 + channels in hippocampal mossy fiber synaptic transmission and long-term potentiation. Neuron 12:261-269.

Castillo PE, Schoch S, Schmitz F, Südhof TC, Malenka RC (2002) RIMlalpha is required for presynaptic long-term potentiation. Nature 415:327-330.

Citron M (2004a) Beta-secretase inhibition for the treatment of Alzheimer's disease-promise and challenge. Trends Pharmacol Sci 25:92-97.

Citron M (2004b) Strategies for disease modification in Alzheimer's disease. Nat Rev Neurosci 5:677-685.

Gray R, Rajan AS, Radcliffe KA, Yakehiro M, Dani JA (1996) Hippocampal synaptic transmission enhanced by low concentrations of nicotine. Nature 383:713-716.

Gu Z, Jiang Q, Fu AK, Ip NY, Yan Z (2005) Regulation of NMDA receptors by neuregulin signaling in prefrontal cortex. J Neurosci 25:4974-4984.

Hardy J, Selkoe DJ (2002) The amyloid hypothesis of Alzheimer's disease: progress and problems on the road to therapeutics. Science 297:353-356.

Harrison SM, Harafter AJ, Hawkins J, Duddy G, Grau E, Pugh PL, Winter PH, Shilliam CS, Hughes ZA, Dawson LA, Gonzalez MI, Upton N, Pangalos MN, Dingwall C (2003) BACE1 (beta-secretase) transgenic and knockout mice: identification of neurochemical deficits and behavioral changes. Mol Cell Neurosci 24:646-655.

Hsieh H, Boehm J, Sato C, Iwatsubo T, Tomita T, Sisodia S, Malinow R (2006) AMPAR removal underlies Abeta-induced synaptic depression and dendritic spine loss. Neuron 52:831-843.

Hu X, Hicks CW, He W, Wong P, Macklin WB, Trapp BD, Yan R (2006) Bacel modulates myelination in the central and afteripheral nervous system. Nat Neurosci 9:1520-1525.

Huang YZ, Won S, Ali DW, Wang Q, Tanowitz M, Du QS, Pelkey KA, Yang DJ, Xiong WC, Salter MW, Mei L (2000) Regulation of neuregulin signaling by PSD-95 interacting with ErbB4 at CNS synapses. Neuron 26:443-455.

Hussain I, Powell D, Howlett DR, Tew DG, Meek TD, Chapman C, Gloger IS, Murphy KE, Southan CD, Ryan DM, Smith TS, Simmons DL, Walsh FS, Dingwall C, Christie G (1999) Identification of a novel aspartic protease (Asp 2) as beta-secretase. Mol Cell Neurosci 14:419-427.

Kim DY, Carey BW, Wang H, Ingano LA, Binshtok AM, Wertz MH, Pettingell WH, He P, Lee VM, Woolf CJ, Kovacs DM (2007) BACE1 regulates voltage-gated sodium channels and neuronal activity. Nat Cell Biol 9:755-764.

Kobayashi K, Manabe T, Takahashi T (1996) Presynaptic long-term depression at the hippocampal mossy fiber-CA3 synapse. Science 273:648-650.

Laird FM, Cai H, Savonenko AV, Farah MH, He K, Melnikova T, Wen H, Chiang HC, Xu G, Koliatsos VE, Borchelt DR, Price DL, Lee HK, Wong PC (2005) BACE1, a major determinant of selective vulnerability of the brain to amyloid-beta amyloidogenesis, is essential for cognitive, emotional, and synaptic functions. J Neurosci 25:11693-11709.

Le Magueresse C, Safiulina V, Changeux JP, Cherubini E (2006) Nicotinic modulation of network and synaptic transmission in the immature hippocampus investigated with genetically modified mice. J Physiol 576:533-546.

Li B, Woo RS, Mei L, Malinow R (2007) The neuregulin-1 receptor erbB4 controls glutamatergic synapse maturation and plasticity. Neuron 54:583-597.

Li Q, Südhof TC (2004) Cleavage of amyloid-beta precursor protein and amyloid-beta precursor-like protein by BACE 1. J Biol Chem 279:10542-10550.

Li R, Lindholm K, Yang LB, Yue X, Citron M, Yan R, Beach T, Sue L, Sabbagh M, Cai H, Wong P, Price D, Shen Y (2004) Amyloid beta peptide load is correlated with increased beta-secretase activity in sporadic Alzheimer's disease patients. Proc Natl Acad Sci U S A 101:3632-3637. 
Liu Y, Ford B, Mann MA, Fischbach GD (2001) Neuregulins increase alpha7 nicotinic acetylcholine receptors and enhance excitatory synaptic transmission in GABAergic interneurons of the hippocampus. J Neurosci 21:5660-5669.

Luo Y, Bolon B, Kahn S, Bennett BD, Babu-Khan S, Denis P, Fan W, Kha H, Zhang J, Gong Y, Martin L, Louis JC, Yan Q, Richards WG, Citron M, Vassar R (2001) Mice deficient in BACE1, the Alzheimer's betasecretase, have normal phenotype and abolished beta-amyloid generation. Nat Neurosci 4:231-232.

Luo Y, Bolon B, Damore MA, Fitzpatrick D, Liu H, Zhang J, Yan Q, Vassar R, Citron M (2003) BACE1 (beta-secretase) knockout mice do not acquire compensatory gene expression changes or develop neural lesions over time. Neurobiol Dis 14:81-88.

Ma H, Lesné S, Kotilinek L, Steidl-Nichols JV, Sherman M, Younkin L, Younkin S, Forster C, Sergeant N, Delacourte A, Vassar R, Citron M, Kofuji P, Boland LM, Ashe KH (2007) Involvement of beta-site APP cleaving enzyme 1 (BACE1) in amyloid precursor protein-mediated enhancement of memory and activity-dependent synaptic plasticity. Proc Natl Acad Sci U S A 104:8167-8172.

Maggi L, Le Magueresse C, Changeux JP, Cherubini E (2003) Nicotine activates immature "silent" connections in the developing hippocampus. Proc Natl Acad Sci U S A 100:2059-2064.

McGehee DS, Heath MJ, Gelber S, Devay P, Role LW (1995) Nicotine enhancement of fast excitatory synaptic transmission in CNS by presynaptic receptors. Science 269:1692-1696.

Nicoll RA, Schmitz D (2005) Synaptic plasticity at hippocampal mossy fibre synapses. Nat Rev Neurosci 6:863-876.

Ohno M, Sametsky EA, Younkin LH, Oakley H, Younkin SG, Citron M, Vassar R, Disterhoft JF (2004) BACE1 deficiency rescues memory deficits and cholinergic dysfunction in a mouse model of Alzheimer's disease. Neuron 41:27-33.

Priller C, Bauer T, Mitteregger G, Krebs B, Kretzschmar HA, Herms J (2006) Synapse formation and function is modulated by the amyloid precursor protein. J Neurosci 26:7212-7221.

Savonenko AV, Melnikova T, Laird FM, Stewart KA, Price DL, Wong PC (2008) Alteration of BACE1-dependent NRG1/ErbB4 signaling and schizophrenia-like phenotypes in BACE1-null mice. Proc Natl Acad Sci U S A 105:5585-5590.

Schmidt JW, Catterall WA (1986) Biosynthesis and processing of the alpha subunit of the voltage-sensitive sodium channel in rat brain neurons. Cell 46:437-444.

Séguéla P, Wadiche J, Dineley-Miller K, Dani JA, Patrick JW (1993) Molecular cloning, functional proafterties, and distribution of rat brain alpha 7: a nicotinic cation channel highly aftermeable to calcium. J Neurosci 13:596-604.

Selkoe D, Kopan R (2003) Notch and Presenilin: regulated intramembrane proteolysis links development and degeneration. Annu Rev Neurosci 26:565-597.
Selkoe DJ (2002) Alzheimer's disease is a synaptic failure. Science 298:789-791.

Sinha S, Anderson JP, Barbour R, Basi GS, Caccavello R, Davis D, Doan M, Dovey HF, Frigon N, Hong J, Jacobson-Croak K, Jewett N, Keim P, Knops J, Lieberburg I, Power M, Tan H, Tatsuno G, Tung J, Schenk D, et al. (1999) Purification and cloning of amyloid precursor protein betasecretase from human brain. Nature 402:537-540.

Sisodia SS, St George-Hyslop PH (2002) gamma-Secretase, Notch, Abeta and Alzheimer's disease: where do the presenilins fit in? Nat Rev Neurosci 3:281-290.

Ting JT, Kelley BG, Lambert TJ, Cook DG, Sullivan JM (2007) Amyloid precursor protein overexpression depresses excitatory transmission through both presynaptic and postsynaptic mechanisms. Proc Natl Acad Sci U S A 104:353-358.

Vassar R (2002) Beta-secretase (BACE) as a drug target for Alzheimer's disease. Adv Drug Deliv Rev 54:1589-1602.

Vassar R, Bennett BD, Babu-Khan S, Kahn S, Mendiaz EA, Denis P, Teplow DB, Ross S, Amarante P, Loeloff R, Luo Y, Fisher S, Fuller J, Edenson S, Lile J, Jarosinski MA, Biere AL, Curran E, Burgess T, Louis JC, et al. (1999) Beta-secretase cleavage of Alzheimer's amyloid precursor protein by the transmembrane aspartic protease BACE. Science 286:735-741.

Vogt KE, Regehr WG (2001) Cholinergic modulation of excitatory synaptic transmission in the CA3 area of the hippocampus. J Neurosci 21:75-83.

Walsh DM, Selkoe DJ (2007) A beta oligomers - a decade of discovery. J Neurochem 101:1172-1184.

Willem M, Garratt AN, Novak B, Citron M, Kaufmann S, Rittger A, DeStrooafter B, Saftig P, Birchmeier C, Haass C (2006) Control of afteripheral nerve myelination by the beta-secretase BACE1. Science 314:664-666.

Wong HK, Sakurai T, Oyama F, Kaneko K, Wada K, Miyazaki H, Kurosawa M, De Strooafter B, Saftig P, Nukina N (2005) beta Subunits of voltagegated sodium channels are novel substrates of beta-site amyloid precursor protein-cleaving enzyme (BACE1) and gamma-secretase. J Biol Chem 280:23009-23017.

Yan R, Bienkowski MJ, Shuck ME, Miao H, Tory MC, Pauley AM, Brashier JR, Stratman NC, Mathews WR, Buhl AE, Carter DB, Tomasselli AG, Parodi LA, Heinrikson RL, Gurney ME (1999) Membrane-anchored aspartyl protease with Alzheimer's disease beta-secretase activity. Nature 402:533-537.

Yang LB, Lindholm K, Yan R, Citron M, Xia W, Yang XL, Beach T, Sue L, Wong P, Price D, Li R, Shen Y (2003) Elevated beta-secretase expression and enzymatic activity detected in sporadic Alzheimer disease. Nat Med 9:3-4.

Zhao J, Fu Y, Yasvoina M, Shao P, Hitt B, O’Connor T, Logan S, Maus E, Citron M, Berry R, Binder L, Vassar R (2007) Beta-site amyloid precursor protein cleaving enzyme 1 levels become elevated in neurons around amyloid plaques: implications for Alzheimer's disease pathogenesis. J Neurosci 27:3639-3649. 